\title{
ANALYSIS OF INDIVIDUAL MICRO-ENTREPRENEUR VISION FROM THE PERSPECTIVE OF FINANCIAL MANAGEMENT
}

\author{
Fabrício Jose de Amorim \\ Braga \\ fabricioamorimbraga@yahoo. \\ com.br \\ Fluminense Federal University - \\ UFF, Niterói, Rio de Janeiro, Brazil.
}

Fabiano de Souza Silvestre f-silvestre@hotmail.com Fluminense Federal University UFF, Niterói, Rio de Janeiro, Brazil.

\section{Ualison Rébula Oliveira} ualison.oliveira@gmail.com Fluminense Federal University UFF, Niterói, Rio de Janeiro, Brazil.

\begin{abstract}
In the business world, the management of an organization calls for the development of information to support decisions. However, this is not a reality for a significant part of micro and small enterprises in Brazil, as several studies have shown. On this theme, with a focus on individual micro-entrepreneurs ${ }^{1}$, the present study investigated how these businesspeople manage their finances and development. Methodologically, the study was supported by field research with 21 entrepreneurs in different business segments from the city of Volta Redonda (Rio de Janeiro state). Results indicated that $19 \%$ of respondents do not control cash flow and $76 \%$ do not analyze their financial results. Of those that use some kind of control, $67 \%$ monitor their finances by handwritten notes in notebooks. Regarding the sales forecast, less than half of the surveyed people do this type of control. Therefore, the surveyed micro-entrepreneurs need to develop financial and accounting management systems, focusing on a better financial control of their businesses. Although not conclusive, we believe the results obtained are related to the respondents' low level of education.
\end{abstract}

Keywords: Individual micro-entrepreneur; Micro and small enterprises; Entrepreneurship; Financial and accounting management.
1 Individual micro-entrepreneurs are similar to sole proprietors in the United States, except they must register the company and can only have one employee at most. 


\section{INTRODUCTION}

According to Toma et al. (2014), entrepreneurship is a multifaceted phenomenon that can be analyzed as a process, action or state of being. According to these authors, through the Schumpeterian view, where new technologies destroy old business models while creating new opportunities, the entrepreneurial process is one of the key factors in the economic development of a country/region.

Economists, sociologists and management scholars have proposed various entrepreneurship definitions and conceptual frameworks for the entrepreneurial process. Entrepreneurship study can be defined as "the study of sources of opportunities; the process of discovery, evaluation and exploitation of opportunities, and the set of individuals who discover, evaluate and exploit them" (Leyden et al., 2014).

In Brazil, most firms are informal: about $75 \%$ of companies are not registered with the National Register of Legal Entities (CNPJ) and do not contribute to the pension system. This feature is even more pronounced among micro-enterprises with up to one employee (Corseuil et al., 2014).

According to the Brazilian Institute of Geography and Statistics (IBGE, 2005), in a survey conducted in 2003, 53\% of informal businesses did not keep any accounting records. This could be linked directly to the fact that only $2 \%$ of micro-entrepreneurs had college diplomas, which in part can accentuate the difficulty of keeping satisfactory accounting records (IBGE, 2005).

In late 2008, through Complementary Law 128, individual micro-entrepreneurship (MEI) list was created (Costanzi et Barbosa Ribeiro, 2011). An individual micro-entrepreneur is defined as having gross income in the previous calendar year of up to $\mathrm{R} \$ 60$ thousand opting for the "Simples $\mathrm{Na}$ cional" tax regime and those who are not disqualified from opting for the system described in Article 966 of Law No. 10,406/2002 (Brasil, 2006).

The main goal of this law was to reduce informality in the Brazilian market, allowing the federal government to increase its revenue, as well as increasing people's access to benefits that only formal workers otherwise enjoy (Paiva et al., 2013).

A study by Borges et al. (2012) of individual micro-entrepreneur profile in a mining town, concluded that the surveyed individuals had low levels of education, were not always willing to acquire new knowledge and ended up missing opportunities to grow their businesses and enjoy all the benefits provided by law.

Morais (2014) evaluated individual micro-entrepreneurs and informal workers in the city of Araranguá and found that interest in legalization is related to social security benefits, access to credit and the possibility of expanding the business. It was also observed that the enhancement of individual micro-enterprises requires greater investment in professional training and business management capacity.

Micro and small enterprises (MSEs) and individual micro-enterprises are the two categories of small businesses in Brazil. According to SEBRAE-NA (2013), in Brazil there are 6.4 million such establishments. Of this total, $99 \%$ are micro and small enterprises (MSEs). MSEs are responsible for $52 \%$ of formal jobs in the private sector (16.1 million) (SEBRAE, 2014). According to SEBRAE (2007), a microenterprise (ME) is a legal entity that receives each year gross income equal to or lower than $\mathrm{R} \$ 240$ thousand. In turn, small businesses (EPPs) receive revenue from $R \$ 240$ thousand to $\mathrm{R} \$ 2.4$ million.

Despite the large number of micro and small enterprises (MSEs), the situation of these companies, although is improving, remains worrying. According to data on the survival rate of companies in Brazil (SEBRAE, 2011a), of every 100 new companies, 27 close in less than two years.

According to Dolabella (1995), financial management plays an important role in managing a company, as it is responsible for providing data on the financial situation of the organization and allows managers to trace their strategies. For to Azeredo et al. (2008), the accounts allow measurement and highlight particular aspects of the economic and financial situation of the company, providing a broad overview of the situation.

In Brazil, the first triennium of this decade saw a strong increase in the creation of new businesses opting for the Simples Nacional tax regime. In December 2012, there were 7.1 million companies registered for the regime. This figure was $26 \%$ higher than in the previous December. In 2011, the expansion was already almost $30 \%$. The survival rate is systematically higher in the Southeast region $(78.2 \%$ for those created in 2007), the only region with survival rate higher than the national average (75.6\% for those created in 2007). Next comes the South (75.3\%), Midwest (74\%), Northeast (71.3\%) and North (68.9\%) (SEBRAE, 2013).

Based on the relevance of micro and small enterprises for the generation of jobs, income and tax revenues, counterbalanced by the high failure rate, the main objective of this study was to investigate the financial management profile of individual micro-entrepreneurs (IME) in the city of Volta Redonda.

In particular, we examine the following questions: i) Do IMEs perform some type of financial control of their businesses? ii) What instruments do they use for this control? iii) 
Do IMEs analyze their financial results? iv) Do IMEs use debt financing? v) Do IMEs make sales forecasts?

Located in the Southeast region, Volta Redonda was the city selected for this empirical study since it is has the largest number of micro and small enterprises in the Middle Paraiba Region (SEBRAE, 2011b).

Methodologically, the data were collected through a field study of 21 individual micro-entrepreneurs in the city of Volta Redonda, with the main objective of analyzing the vision of this segment of entrepreneurs regarding financial management.

In terms of organization, this paper is structured as follows: section 2 develops the theoretical reference on individual micro-entrepreneurs, informality, municipal data of Volta Redonda and financial management. Section 3 presents the research method. Section 4 organizes and discusses the results. Finally, the conclusion ends the study with recommendations for future research.

\section{THEORETICAL REFERENCE}

This section presents the theoretical foundation of the research, starting with an overview of individual micro-entrepreneurs with emphasis on informality. Information on the city of Volta Redonda is presented, emphasizing the number of micro and small enterprises of the cities in the Middle Paraiba Region, focusing on the evolution of the number by size of establishments in Volta Redonda. The section concludes with comments on financial management and accounting.

\subsection{Individual micro-entrepreneurs (IMEs) and informality}

Since the end of last century, the economic environment has undergone a revolution, affected by phenomena such as globalization, volatility, convergence, technological innovation, competitiveness and differentials (services). These changes require increasingly flexible attitudes, creativity, productivity, quality, and forecasting ability of managers to achieve their long-term survival goals (Ost, 2007).

The Law of Individual Micro-Entrepreneurs (Law No. $128 / 2008$ ) was enacted with the aim of encouraging self-employed people in the informal sector to regularize their situations (Oliveira et Strong, 2014).

According to the Portal do Empreendedor (2014) individual micro-entrepreneurs are people working on their own and that have legalized small businesses. To be an individual micro-entrepreneur, the person must gain a maximum to $\mathrm{R} \$$ $60,000.00$ per year and have no stake in another company as partner or owner. The IME can also have one employee, receiving the minimum monthly wage or prevailing wage.

Companies with these characteristics are eligible for the Simples Nacional regime, which exempts them from federal taxes (income tax, PIS, COFINS, IPI and pension contribution) and simplifies the process of paying municipal and state taxes and reduces the rates (Brasil, 2008)

Informal companies include economic units that produce some type of service or good that generates employment and income (Pathak et Muralidharan, 2016), traditionally characterized by small-scale production, low administrative costs and without clear separation of business and personal assets (Pochmann, 2005).

Likewise et al. (2005) consider that informal work can be characterized by small-scale production, reduced use of technology and unclear separation between capital and labor, in addition to engaging, in some cases, in economic activities outside the law and devoid of protection or public regulation.

According to Silva et al. (2010), the large Brazilian informal market arises due to the complex and costly regulation of formal work that results in the loss of economic dynamism and unemployment, also caused by technological innovation or recessive economic times. However, informality emerges as an alternative for income generation and sustainability for excluded groups, either by technical backwardness or surplus labor in the market.

In turn, according to the Ministry of Labor and Employment (2002), the high informality in the Brazilian labor market has three explanatory factors:

1) The new forms of labor relationships and business organization, which increase the number of self-employed people;

2) Loss of labor from traditional sectors (manufacturing) to sectors with higher degree of informality, such as services and commerce, and to outsourcing;

3) Finally, factors associated with the system of social security and labor laws, encouraging the establishment of many informal working relationships by companies and their employees.

Allied to these factors above, Fucs (2010) points out that the national tax system in Brazil is not only burdensome, but also complex, composed of a welter of taxes, contributions, fees and other levies. According to Pereira (2010), a com- 
pany needs to have good tax planning, since today the tax burden is the most negative element affecting businesses.

For these and other reasons, the number of enterprises in the informal sector in 2003 surpassed ten million (IBGE, 2005). With the enactment of Complementary Law No. $128 / 2008$, establishing the legal form of the individual micro-entrepreneur, the government expected this number to steadily decrease.

The individual micro-entrepreneur category gives an opportunity for growth and development for those who are informal, offering means to stay in the market and thus leverage their enterprise and generate new jobs and opportunities (SEBRAE, 2010).

Among the advantages offered for establishing a formal company, by means of the registration on the National Register of Legal Entities (CNPJ), is the ability to open bank accounts and obtain loans. This comes with the obligation to issue invoices and pay the corresponding taxes.

In addition, the individual micro-entrepreneurs are entitled to various benefits, such as sick pay, maternity aid and retirement (from the National Social Security Institute - INSS), among others. Individual micro-entrepreneurs must satisfy the following requirements (Brasil, 2006; Brasil, 2008):

- Have no obstruction according to Complementary Law 123/06;

- Opt for taxation under the Simples Nacional regime;

- Do not receive gross revenue of more than $\mathrm{R} \$ 60$ thousand per year or the proportional limit shown in Table 1

Table 1. Time in business proportional upper revenue limit for IMEs.

\begin{tabular}{cc}
\hline Time of activity (in months) & Proporcional limit (in R\$) \\
\hline 12 & $60,000.00$ \\
11 & $55,000.00$ \\
10 & $50,000.00$ \\
9 & $45,000.00$ \\
8 & $40,000.00$ \\
7 & $35,000.00$ \\
6 & $30,000.00$ \\
5 & $25,000.00$ \\
4 & $20,000.00$ \\
3 & $15,000.00$ \\
2 & $10,000.00$ \\
1 & $5,000.00$ \\
\hline
\end{tabular}

Source: Ministry of Labor and Employment (2012).
According to the data of the Urban Informal Economy Survey (IBGE, 2005), conducted by IBGE in 2003, the informal economy generated US\$ 17.6 billion in revenue in that year and was responsible for a quarter of non-agricultural workers in the country. In October 2003 there were $10,525,954$ small non-agricultural enterprises, of which $98 \%$ were in the informal sector. Among the states, São Paulo, Minas Gerais, Rio de Janeiro, Bahia and Rio Grande do Sul concentrated together $57.6 \%$ of enterprises in the informal sector (IBGE, 2014a).

\subsection{The city of Volta Redonda}

The state of Rio de Janeiro is composed of 92 municipalities $^{1}$ cities in eight regions: Metropolitan, Northwest Fluminense, North Fluminense, Serrana (mountain), Baixada Litorânea (coastal lowlands), Middle Paraíba, South-Central Fluminense and Costa Verde.

Volta Redonda is situated on the banks of the Paraíba do Sul River, where Companhia Siderúrgica Nacional (CSN, or "National Steel Company") was established in 1946 (Klein, Araujo et Leal, 1985).

According to the IBGE (2014b), the city of Volta Redonda belongs to the Middle Paraíba Region, along with Barra do Piraí, Barra Mansa, Itatiaia, Pinheiral, Piraí, Porto Real, Quatis, Resende, Rio Claro, Rio das Flores and Valença. It has an estimated population of 262,259 inhabitants, with a land area of $182,483 \mathrm{~km}^{2}$ and a Municipal Human Development Index (IDHM, 2010) of 0.771 .

Based on data extracted from the Annual List of Social Information (RAIS, 2010), released by the Ministry of Labor and Employment, Figure 1 shows the number of micro and small enterprises of the cities of the Middle Paraíba Region. Volta Redonda has the highest number (SEBRAE, 2011b).

Figure 2 shows the evolution of the number of establishments from 2009 to 2010, in Volta Redonda. Micro enterprises represented $91.0 \%$ of the total formal establishments in Volta Redonda and the highest concentration of these companies was in the retail sector (SEBRAE, 2011b).

1 The municipality is the local administrative unit in Brazil. It is akin to a county, except with a single mayor and municipal council. Municipalities range from lightly populated rural areas with one or two small towns to heavily populated urban regions that are part of greater metropolitan regions. There are no unincorporated areas in Brazil. 


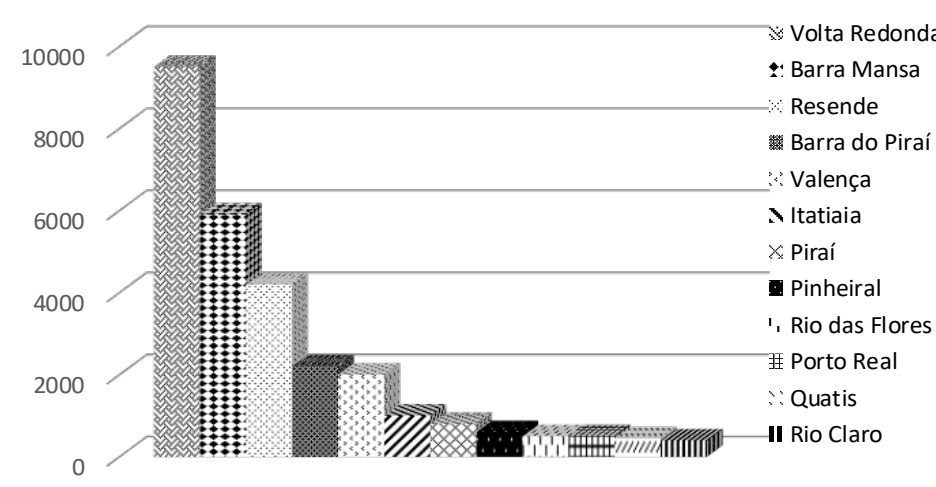

Figure 1. Number of MPEs in cities of the Middle Paraiba Region. Source: SEBRAE (2011b).

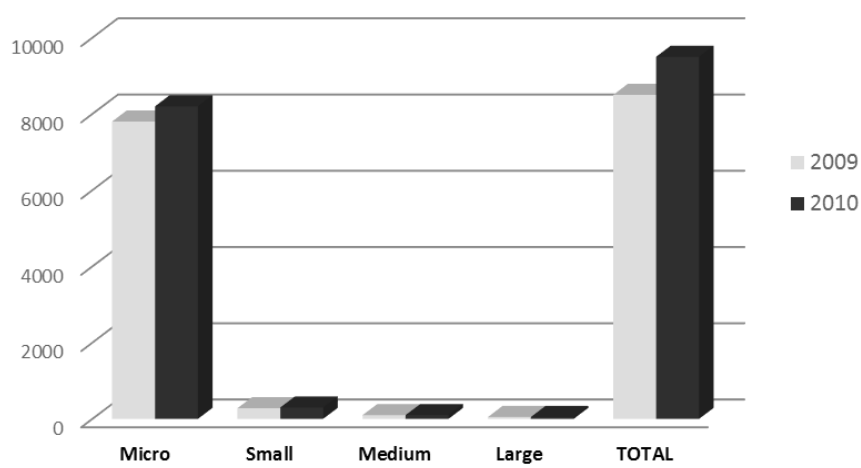

Figure 2. Evolution of establishments in the city of Volta Redonda. Source: SEBRAE (2011b).

\section{Financial management and accounting}

Financial management can be defined as the management of monetary flows from operating activities of a company in terms of their respective occurrences in time. It aims to find the balance between "profitability" (maximization of returns) and "liquidity" (ability to honor financial commitments within contracted deadlines). Thus, financial management is necessary to balance generating profits and maintaining cash (Cheng et Mendes, 1989).

According to Dolabella (1995), a company's management system can be analyzed in three interrelated dimensions: operational, economic and financial, and the last one aims to ensure the company's liquidity.

As explained by Vaz et Menezes (2006), among the management challenges are those related human resources, production process and financial affairs, among others. The working capital management is extremely dynamic, requiring daily attention of executives. Any failure in this area can compromise the solvency of the company or impair its profitability.
In recent decades, management accounting has increasingly gained importance within organizations, as a fundamental tool for the pursuit of efficiency and cost containment (Macinati et Anessi-Pessina, 2014).

Accounting is responsible for providing information, meeting the new challenges, seeking data that meet the needs of stakeholders (concerned parties) (Daneberg, et al., 2014; Gill et al., 2017).

According to Carneiro et al. (2008), among the many purposes of accounting is to act as a disclosure channel with society, allowing the identification, measurement and analysis of economic, financial, social and environmental events.

For Marion (1998) "Accounting can be considered as an information system designed to provide the data to users to help them make decisions". Dolabella (1995) affirms that the financial function comprises a set of activities related to the management of funds handled by all areas of the company. This function is responsible for obtaining the necessary resources and the formulation of a strategy to optimize the use of these funds, since financial functions play an important role in the development of all operational activities, contributing significantly to the success of the enterprise.

\section{RESEARCH METHOD}

This paper addresses the practices of individual micro-entrepreneurs in Volta Redonda regarding financial management. The method is qualitative, descriptive and exploratory, based on literature review and primary data from a field survey.

The published data came basically from four sources: a) Scielo; b) Web of Science (WoS); c) studies conducted by SEBRAE; and d) laws related directly and indirectly to IMEs. The data from the academic literature were obtained by using the following search expressions: "micro e pequenas empresas", "micro empreendedor individual" and "pequenas empresas" (Scielo); and "microentrepreneurship", "microenterprise" and "small firms" (WoS).

The field survey involved the application of a questionnaire composed of eleven closed questions. It was previously validated through a pilot test with three other micro-entrepreneurs in the same field, but separately.

The questionnaire contained simple questions to facilitate the understanding of respondents, and covered issues on financial planning, result analysis, loans, cash-flow control, control of accounts payable and receivable, and sales forecasting, among others. Twenty-one micro-entrepre- 
neurs in different business segments took part in the survey, conducted at a marketplace in the city of Volta Redonda.

The micro-entrepreneurs were chosen based on the following three parameters: i) diversity of products and services typically sold by micro-entrepreneurs in the city; ii) their presence in this marketplace, which has a privileged geographical location; and iii) ease of access to micro-entrepreneurs by one of the researchers, since the majority of the people surveyed are customers of Banco do Brasil, where this researcher is the Corporate Relationship Manager. Thus, we used an intentionally non-probabilistic sample of 21 small businesses from a total of 24 located in that marketplace. It should be mentioned that the marketplace has adequate infrastructure and is supported by the municipal government of Volta Redonda.

\section{RESULTS AND DISCUSSION}

Based on the data collected by this survey, it was observed that only $5 \%$ of respondents had completed higher education, while $52 \%$ had not finished $9^{\text {th }}$ grade. Therefore, a general low level of education was evident, which can be directly related to the results. This is not a conclusive finding, but an assumption that the elements are related to, since it is reasonable to assume that the level of education has a direct influence on financial management issues and their control.

One result that stood out was the method used by the respondents to keep track of their finances. About two-thirds of them control this through figures written in notebooks and $19 \%$ do not perform any kind of control. Figure 3 illustrates these results.

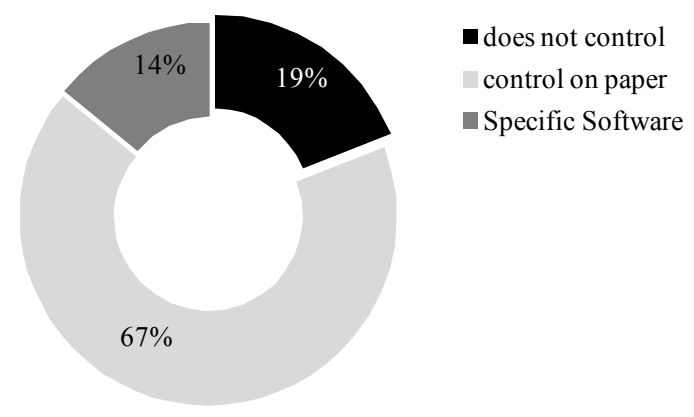

Figure 3. Cash flow control by micro-entrepreneurs. Source: Prepared by the authors.

According to Rikhardsson et Impgaard (2004), successful management requires having relevant information to guide decision making. Dolabella (1995) points out that financial management has an important role in managing the company, as it is responsible for providing data on the financial sit- uation of the organization and therefore, it allows managers to trace out their strategies.

We believe that it is not the lack of resources that prevents the use of electronic spreadsheets in managing cash flow and financial matters in general, but the existence of a culture characterized by resistance and/or technical inability to use new technologies. The low use of Microsoft Excel, as shown in Figure 4, is a clear example, in line with the scenario presented by the previous figure.

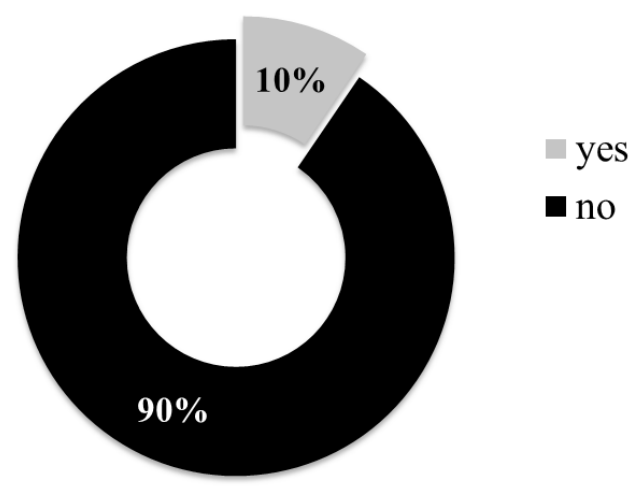

Figure 4. Use of Excel spreadsheets to control cash flow Source: Prepared by the authors.

The use of this program does not require great technical knowledge; thus, it is the best program for financial record-keeping in micro-enterprises, since typically these companies do not have financial means to invest in specific software. This reinforces the observation of the previous paragraph, i.e., the lack of computer knowledge and the lack of interest and resistance to change of micro-entrepreneurs.

During the literature review, it was noted that cash flow is one of the most effective tools of financial planning and control, thus becoming a basic element for administrators to assess the financial position of the company in the long term (Quintana et Saurin, 2008). A precise cash flow forecast is essential for successful management and is especially important in volatile market and uncertain credit conditions (Tangsucheeva et Prabhu, 2014). Without an accurate prediction of cash flow, the company may fail to meet its short-term obligations and may be in danger of bankruptcy. If the forecast cash flow is not accurate, the company can be limited by a number of factors, including changes in macroeconomic conditions that influence liquidity in the economy, varying customer payment behavior and dynamics of the supply chain.

According to Batista et al. (2012), in their study of the mortality of micro and small enterprises in Sousa, Paraíba state, small business owners have resistance to implementing a planning process and creating a database. These micro-entrepreneurs believe that strategic planning is an issue 
Brazilian Journal of Operations \& Production Management

Volume 15, Número 2, 2018, pp. 182-192

DOI: 10.14488/BJOPM.2018.v15.n2.a2 faced only by large companies with expensive projects, high amounts of customers and many managers.

Table 2 identifies the financial management activities carried out by the micro-entrepreneurs in the city of Volta Redonda, including analysis of financial results, planning of financial resources, monitoring of accounts payable and receivable, recording of costs and expenses, as well as the classification of costs into fixed and variable.

Table 2. Activities undertaken by Volta Redonda individual microentrepreneurs

\begin{tabular}{ccc}
\hline \multirow{2}{*}{ Activities } & \multicolumn{2}{c}{ Results (n=21) } \\
\cline { 2 - 3 } & Yes & No \\
\hline Analysis of financial figures. & $24 \%$ & $76 \%$ \\
$\quad \begin{array}{c}\text { Financial resources planning } \\
\text { Monitoring of accounts payable and re- } \\
\quad \text { ceivable, through payment flows }\end{array}$ & $71 \%$ & $29 \%$ \\
$\quad \begin{array}{c}\text { Recording costs and expenses } \\
\text { Classification of costs into fixed and } \\
\text { variable }\end{array}$ & $86 \%$ & $38 \%$ \\
\hline & $52 \%$ & $48 \%$ \\
\hline & Source: Prepared by the authors.
\end{tabular}

According to Table 2, in general, financial management among the micro-entrepreneurs surveyed in Volta Redonda is inefficient: $76 \%$ of them do not analyze their financial results. This demonstrates the unpreparedness and lack of interest of most micro-entrepreneurs analyzed. It also shows a lack of control in the structuring of business data, to enable measurement and comparison with past patterns.

On the positive side, most micro-entrepreneurs in this study $(71 \%)$ plan the use of financial resources while the minority of them (29\%) does not (Table 2). According to Chan et Chen (1991), companies in financial difficulties, such as those that have lost market value because of poor performance, are inefficient producers and are likely to have financial problems with cash flow. They also tend to be more sensitive to changes in the economy and are less likely to survive adverse economic conditions.

Table 2 shows that $62 \%$ of respondents monitor their accounts payable and receivable. This is good for the financial health of the company; however, it is not enough to ensure some security for the business. On the other hand, 38\%, which is a very high percentage for an item of prime importance for the financial health of companies, do not do this, putting them at the mercy of "luck", and increasing the possibility of failure.

According to the data from Vaz et Gomes (2011), many companies are created every day in Brazil; however, many of them cannot survive and end up closing their doors within five years time. Among the various factors that lead these companies to close are the lack or incorrect management and control of inventories. This particularly affects small and medium-sized enterprises, as they do not often have qualified people to perform such function or have one person to perform several functions, such as buyer, manager, financial controller, and shop attendant, etc.

Most of the studied micro-entrepreneurs (86\%) know what costs and expenses are, while $52 \%$ of them understand the definitions of fixed and variable costs. These items are important for planning the company's budget, and the control of these costs is very important for the health of the company (Table 2).

High efficiency and total management of costs are fundamental to the success of any economy. These qualities are the only way to stay competitive, control costs and maintain the quality of products in an intensely competitive environment with decreasing profit margins and market shares (Assaf Neto et al., 2001).

Figure 5 shows the use of loans by the micro-entrepreneurs. Most of the respondents (76\%) stated they have no loans while $24 \%$ have some type of loan or financing. These percentages are related to the lack of planning for company's growth, where resources such as working capital and investments are not being used, or the entrepreneur fears expanding the business (Figure 5).

Kevane et Wydick (2001) said that the previous two decades had witnessed an unusual proliferation of micro-credit programs throughout the developing world. The granting of credit to micro companies seeks to stimulate economic growth in the informal sector by promoting better capitalized companies, job creation and growth of long-term income.

Goulart (2013) investigated the profile and characteristics of individual micro-entrepreneurs who were customers of a bank in the city of Criciúma (Santa Catarina) and found out that most had obtained loans, which helped to promote the business, noted in the reported increase of sales.

The sales forecasting of micro-entrepreneurs is shown in Figure 6 , revealing the majority (52\%) forecast their sales. This is a good practice for planning the future of the company in the short term and focusing on the way they want to follow. However, $48 \%$ do not do this forecasting, which can contribute to the premature mortality of the company, demonstrating once again the lack of business planning and direction (Figure 6). The lack of sales forecasting prevents companies from making financial projections in medium and long term. 


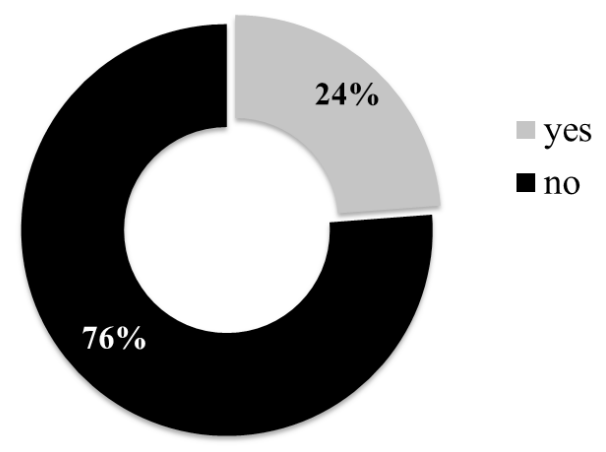

Figure 5. Use of loans by micro-entrepreneurs Source: Prepared by the authors.

This result demonstrates a lack of business vision (myopia) and a lack of interest in business growth, as well as bad budget management by the majority of micro-entrepreneurs, who seem to be satisfied with their current situation.

According to Acquaah (2013), in contemporary competitive, complex and globally changing business environment, companies are challenged to adopt business models that enable them to meet strategic uncertainties and face risks in their business environments. Simons (2000) and Widener (2007), accounting management researchers, argue that one of the ways in which companies can continuously rejuvenate to survive and succeed in these complex and uncertain environments is to understand the role of management control systems in creating competitive advantages.

A study conducted by SEBRAE (2014) evaluated the MSE purchasing system set up by the U.S. government and found out that, under the regulation of the Small Business Act, 1953 , federal agencies are required to purchase at least $23 \%$ of their supplies from small businesses. The most noteworthy example comes from NASA, which, despite its high quality and technology requirements, spends $31 \%$ of its budget purchasing goods and services from American MSEs, when the law requires it to buy only $8 \%$. Meanwhile, the Brazilian MSEs account for only $2 \%$ of exports. In Italy this percentage exceeds $50 \%$, the result of a vigorous policy of incentives and protections, which for decades has driven micro and small businesses in that country. In Spain and France, there are similar mechanisms (SEBRAE, 2014).

Figure 7 shows the evolution of the assets of the company, necessary to know the bottom-line profitability. The largest contingent (48\%) of the surveyed micro-entrepreneurs does not monitor the evolution of the company's assets. This can cause false impressions of performance, and, in extreme situations, even bankruptcy.

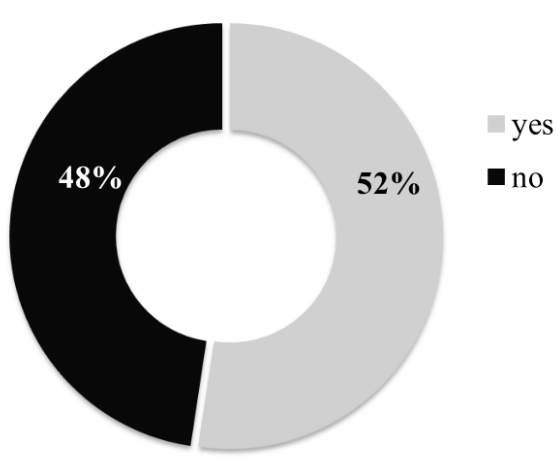

Figure 6. Micro-entrepreneurs that make sales forecasts Source: Prepared by the authors.

Deberry-Spence et Elliot (2012) described a number of factors that restrict micro-entrepreneurship, such as lack of financial capital and cash reserves, poor management skills, inadequate advice, deficiencies in technology, insufficient support services, ineffective rights or property protection, lack of access to credit and the difficulty of access to export markets. Factors include deficiencies in terms of learning and knowledge development, social networks and infrastructure.

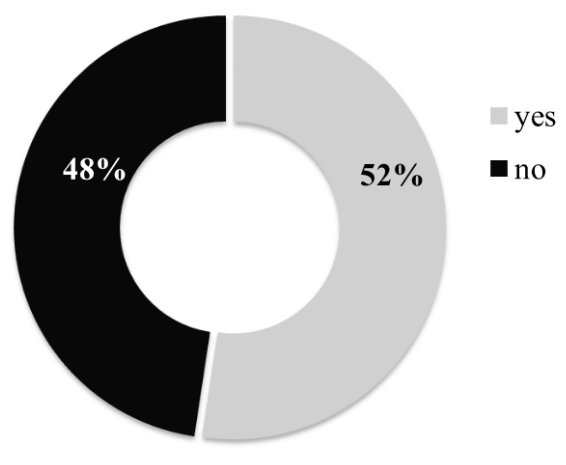

Figure 7. Monitoring evolution of business assets and profitability Source: Prepared by the authors.

In a globalized scenario, in which information can be found more quickly and easily, many small entrepreneurs are unresponsive or unmotivated to improve and/or unprepared to manage their businesses. The results found here reveal that many of micro-entrepreneurs are not ready to face challenges effectively and make their businesses grow and prosper, for the simple lack of interest in the search for knowledge and preparation to manage a microenterprise.

Figure 8 condenses and organizes all results found. 
D Brazilian Journal of Operations \& Production Management

Volume 15, Número 2, 2018, pp. 182-192

DOI: 10.14488/BJOPM.2018.v15.n2.a2
SUMMARY OF RESULTS

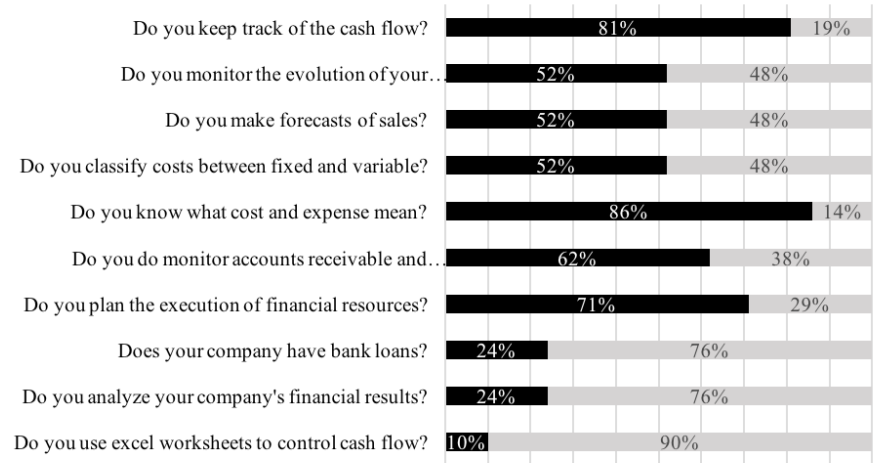

- NO $₫$ YES

Figure 8. Summary of results

Source: Prepared by the authors.

\section{CONCLUSION}

Financial management involves a set of actions and procedures related to monitoring certain indicators, which have the objective of maximizing the economic and financial results of a company. These results, being positive or negative, end up influencing all other areas of the organization; and this is no different in micro and small enterprises (MSEs).

Since this type of organization is considered one of the main pillars of the Brazilian economy because of its ability to generate jobs, the utility of this study is justified and its goals achieved, i.e., to investigate the individual micro-entrepreneur profile.

The research in question was able to identify relevant issues such as low educational level, lack of control of cash flow and the low use of effective tools to control it, such as Excel worksheets. It is important to highlight, though, that the percentage of entrepreneurs who control their finances through written notes in notebooks was not expected to be so high, (67\%). In this respect, only $14 \%$ of the respondents keep track of financial flows with the use of some type of software. In terms of long-term sales forecasting, for example, we found that $48 \%$ do not make any kind of prediction. Thus, by induction, it is believed that this combination of results is one of the reasons (or the main reason) that the mortality rate of MSEs is high (around $27 \%$ ), as shown in the literature review of this study.

As positive results, it was observed that, apparently, 76\% of the entrepreneurs surveyed are not indebted. It is "apparently" because it could mean a lack of vision in the use of credit, which would leverage aspects related to this type of organization.
Finally, despite this empirical study was conducted with a sample of only 21 micro-entrepreneurs, it is believed that this type of result is common in the business world. However, due to the impossibility of generalization of our findings; and since the selection of the companies surveyed was non-probabilistic and intentional, further research based on statistical models is recommended, aiming at random selection of an adequate number of companies from this segment, so that the result of the sample may be more reliably attributed to the entire population.

\section{REFERENCES}

Acquaah, M. (2013), "Management control systems, business strategy and performance: a comparative analysis of family and non-family businesses in a transition economy in sub-Saharan Africa", Journal of Family Business Strategy, Vol. 4, No. 2, pp. 131-146.

Assaf, S. A.; Bubshait, A. A.; Atiyah, S. (2001), "The management of construction company overhead costs", International Journal of Project Management, Vol. 19, No. 5, pp. 295-303.

Azeredo, A. J.; Souza, M. A.; Machado, D. G. (2009), “Desempenho econômico-financeiro de indústrias calçadistas brasileiras: uma análise do período de 2000 a 2006", Revista de Contabilidade e Organizações, Vol. 3, No. 6, pp. 117-142.

Batista, F. F.; Freitas, E. C.; Santiago, J. S. (2012), “Uma Investigação acerca da Mortalidade das Microempresas e Empresas de Pequeno Porte da Cidade de Sousa, PB", REUNIR - Revista de Administração, Contabilidade e Sustentabilidade, Vol. 2, No. 1, pp. 56-71.

Borges, G. F.; Borges, L. F.; Brito, N. et al. (2012), "Perfil do microempreendedor individual: um estudo exploratório em um município mineiro", Sinad - Simpósio Nacional de Administração. UFLA.

Brasil (2006), Lei Complementar no 123, de 14 de dezembro de 2006, Institui o Estatuto Nacional da Microempresa e da Empresa de Pequeno Porte, Diário Oficial da União, 15 dez.

Brasil (2008), Lei Complementar no 128, de 19 de dezembro de 2008, Altera a Lei Complementar no 123, de 14 de dezembro de 2006 e dá outras providências, Diário Oficial da União, 22 dez.

Carneiro, J.E.; De Luca, M.M.M.; Oliveira, M.C. (2008), "Análise das informações ambientais evidenciadas nas demonstrações financeiras das empresas petroquímicas brasileiras listadas na Bovespa", Revista Contabilidade Vista e Revista, Vol. 19, No. 3, pp. 39-67.

Chan, K.C.; Chen N.-F. (1991), "Structural and return characteristics of small and large firms", Journal of Finance, Vol. 46 , pp. $1467-1484$. 
Cheng, A.; Mendes, M.M. (1989), “A importância e a responsabilidade da gestão financeira na empresa", Caderno de Estudos, Vol. 1, pp. 1-10.

Corseuil, C.H.L.; Neri, M.C.; Ulyssea, G. (2014), Uma análise exploratória dos efeitos da política de formalização dos microempreendedores individuais, Texto para discussão, Instituto de Pesquisa Econômica Aplicada, Brasília; Rio de Janeiro.

Costanzi, R.N.; Barbosa, E.D.; Ribeiro, H.M. (2011), “A experiência do microempreendedor individual na ampliação da cobertura previdenciária no Brasil", Revista do Serviço Público Brasília, Vol. 62, Vol. 4, pp. 387-406.

Daneberg, T.F.; Tinoco, J.E.P.; Claro, J.A.C. (2014), “Evidenciação econômica, financeira e socioambiental de empresas brasileiras de água e saneamento básico", Caderno Profissional de Administração da UNIMEP, Vol. 4, No. 1, pp. 45-66.

Deberry-Spence, B.; Elliot, E.A. (2012), "African microentrepreneurship: the reality of everyday challenges", Journal of Business Research, Vol. 65, No. 12, pp. 1665-1673.

Dolabella, M.M. (1995), Mensuração e simulação das necessidades de capital de giro e dos fluxos financeiros operacionais: um modelo de informação contábil para a gestão financeira, Dissertação de Mestrado em Contabilidade, Faculdade de Economia, Administração e Contabilidade, São Paulo.

Fucs, J. (2010), “A trava dos impostos”, Época, No. 632, pp. 57-57.

Gill, A.; Gurau, C.; Dana, L.; Sanchez, C. R. (2017), “Human capital, financial strategy and small firm performance: a study of Canadian entrepreneurs", International Journal of Entrepreneurship and Small Business, Vol. 31, No. 4, pp. 492-513.

Gomes, J.A.; Freitas, A.A.F.; Capelo Júnior, E. (2005), “O retrato do empreendedor informal", em: Encontro Nacional de Engenharia de Produção, Porto Alegre, 2005, Anais do XXV Encontro Nacional de Engenharia de Produção, Porto Alegre, ENEGEP.

Goulart, A. (2013), Perfil e características do microempreendedor individual clientes de uma agência bancária do município de Criciúma - SC, Trabalho de Conclusão de Curso em Administração, Universidade do extremo Sul Catarinense, Criciúma, SC.

Instituto Brasileiro de Geografia e Estatística - IBGE (2005), Economia Informal Urbana 2003, IBGE, Rio de Janeiro.

Instituto Brasileiro de Geografia e Estatística - IBGE (2014), Cidades, disponível em: https://cidades.ibge.gov.br (acesso em 15 dez. 2017).

Kevane, M.; Wydick, B. (2001), “Microenterprise lending to female entrepreneurs: sacrificing economic growth for poverty alleviation?", World Development, Vol. 29, No. 7, pp. 1225-1236.
Klein, C.H.; Araujo, J.W.; G.; Leal, M.C. (1985), “Inquérito epidemiológico sobre hipertensão arterial em Volta Redonda - RJ", Caderno de Saúde Pública, Vol. 1, No. 1, pp. 58-70.

Leyden, D.; Link, A.N.; Siegel, D.S. (2014), “A theoretical analysis of the role of social networks in entrepreneurship', Research Policy, Vol. 43, No. 7, pp.1157-1163.

Macinati, M.S.; Anessi-Pessina E. (2014), “Management accounting use and financial performance in public health-care organisations: Evidence from the Italian National Health Service", Health Policy, Vol. 117m No. 1, pp. 98-111.

Marion, J.C. (1998), Contabilidade Empresarial, 8. ed., Atlas, São Paulo.

Ministério do Trabalho e Emprego - MTE (2002), A informalidade no mercado de trabalho brasileiro e as políticas públicas do governo federal, MTE, Brasília.

Morais, I.L. (2014), Microempreendedores individuais (MEl'S): um estudo da legalização de trabalhadores informais na cidade de Araranguá/SC, Trabalho de Conclusão de Curso em Administração, Universidade do Extremo Sul Catarinense.

Oliveira, O.V.; Forte, S.H.A.C. (2014), “Microempreendedor Individual: fatores da informalidade", Connexio, Vol. 4, pp. 27 42.

Ost, J.E. (2007), Estratégias competitivas das empresas do setor hoteleiro de Curitiba diante das redes hoteleiras nacionais e internacionais, Dissertação de Mestrado. Centro Universitário Positivo.

Paiva, D.M.; Pereira, J.C.; Pereira, P.H. (2013), “O programa Microempreendedor Individual: uma alternativa para redução do emprego informal", Publicatio UEPG: Ciências Sociais Aplicadas, Vol. 21, No. 2, pp. 193-201.

Pathak, S. Muralidharan, E. (2016), "Informal Institutions and Their Comparative Influences on Social and Commercial Entrepreneurship: The Role of In-Group Collectivism and Interpersonal Trust", Journal of Small Business Management, Vol. 54, No. 1, pp. 168-188.

Pereira, V.M. (2010), Um estudo comparativo entre a pessoa jurídica do Microempreendedor individual e o regime tributário do simples Nacional, Trabalho de Conclusão de Curso, Universidade Federal de Santa Catarina, Florianópolis.

Pochmann, M. (2005), Economia do Microempreendimento Informal no Brasil, SEBRAE, Brasília.

Portal do Empreendedor (2014), O que é o MEI - Microempreendedor Individual?, disponível em: http://www. portaldoempreendedor.gov.br/duvidas-frequentes/o-microempreendedor-individual-mei/1-o-que-e-o-mei-microempreendedor-individual (acesso em $14 \mathrm{dez}$. 2017).

Quintana, A. C.; Saurin, V. (2008), “Análise da utilização da demonstração do fluxo de caixa como um instrumento de gestão financeira nas sociedades anônimas de capital aberto 
do Estado do Rio Grande do Sul", Revista de Ciências da Administração, Vol. 10, No. 22, pp. 55-79.

Rikhardsson, P.M.; Impgaard M. (2004), "Corporate cost of occupational accidents: an activity-based analysis", Accident Analysis \& Prevention, Vol. 36, No. 2, pp. 173-182.

Serviço Brasileiro de Apoio às Micro e Pequenas Empresas - SEBRAE (2007), Lei Geral das MPE, disponível em: http:// www.sebrae.com.br/sites/PortalSebrae/ufs/ro/artigos/a-lei-geral-das-mpe,07597640b34b6510VgnVCM1000004c00210 aRCRD (acesso em 17 dez. 2017).

Serviço Brasileiro de Apoio às Micro e Pequenas Empresas - SEBRAE (2010), Maioria dos empreendedores individuais é do comércio varejista, disponível em: http://www.administradores.com.br/noticias/negocios/maioria-dos-empreendedores-individuais-e-do-comercio-varejista/39093/ (acesso em 17 dez. 2017).

Serviço Brasileiro de Apoio às Micro e Pequenas Empresas - SEBRAE (2011a), Taxa de sobrevivência das empresas no Brasil, SEBRAE, Brasília.

Serviço Brasileiro de Apoio às Micro e Pequenas Empresas - SEBRAE (2011b). Informações Socioeconômicas do Município de Volta Redonda, SEBRAE, Rio de Janeiro.

Serviço Brasileiro de Apoio às Micro e Pequenas Empresas - SEBRAE (2013), GEOR - Gestão Estratégica Orientada para Resultados, Sobrevivência das empresas no Brasil, SEBRAE, Brasília.

Serviço Brasileiro de Apoio às Micro e Pequenas Empresas - SEBRAE (2014), Pequenos Negócios em Números, dis- ponível em: http://www.sebrae.com.br/sites/PortalSebrae/ ufs/sp/sebraeaz/pequenos-negocios-em-numeros,12e8794363447510VgnVCM1000004c00210aRCRD (acesso em 17 dez. 2017).

Silva, N.P. Francisco, A.C.; Silva, M.C.G. (2010), "A importância do empreendedor rural para capacitar, desenvolver e equacionar estrategicamente os recursos sustentáveis, gerando renda e qualidade de vida", Revista e-ESTUDANTE - Electronic Accounting and Management, Vol. 2, No. 2, pp. 1-12.

Simons, R. (2000), "Performance measurement and control systems for implementing strategy", Prentice-Hall, Upper Saddle River, NJ.

Tangsucheeva, R.; Prabhu, V. (2014), "Stochastic financial analytics for cash flow forecasting", International Journal of Production Economics, Vol. 158, pp. 65-76.

Toma, S-G.; Grigore, A-M.; Marinescu, P. (2014), "Economic Development and Entrepreneurship", Procedia Economics and Finance, Vol. 8, pp. 436-443.

Vaz, L.A.C.; Menezes, E.A. (2006), "Gestão financeira das cooperativas: aplicação do modelo dinâmico", Revista Gestão Industrial, Vol. 2, No. 2, pp. 133-145.

Vaz, R.A.P.; Gomes, S. (2011), "Gestão de estoques nas micro e médias empresas: um estudo de caso na empresa madeireira Catalana Ltda", Revista do Centro de Extensão, Pesquisa e Pós-Graduação, Vol. 24, pp. 119-135.

Widener, S.K. (2007), "An empirical analysis of the levers of control framework", Accounting, Organizations and Society, Vol. 32, pp. 757-788.

Received: 26 Sept 2016

Approved: 08 May 2018

DOI: 10.14488/BJOPM.2018.v15.n2.a2

How to cite: Braga, F. J. A., Silvestre, F. S., Oliveira, U. R. (2018), "Analysis of individual micro-entrepreneur vision from the perspective of financial management", Brazilian Journal of Operations \& Production Management, Vol. 15, No. 2, pp. 182-192, available from: https://bjopm.emnuvens.com.br/bjopm/article/view/337 (access year month day). 